
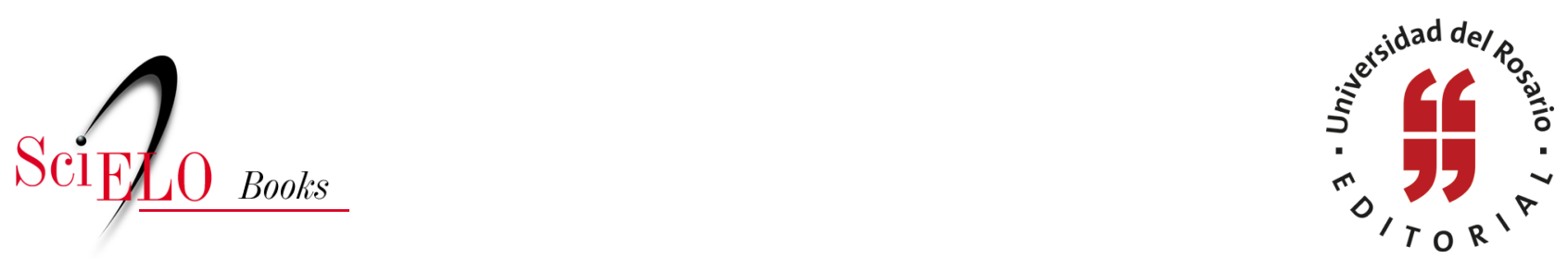

\title{
22. De recuerdos, memorias y nostalgias
}

\author{
César Augusto Tapias Hernández
}

\section{SciELO Books / SciELO Livros / SciELO Libros}

TAPIAS HERNÁNDEZ, C.A. De recuerdos, memorias y nostalgias. In: Historias de familia: Etnografía delirante sobre el amor, la violencia y las drogas [online]. Bogotá: Editorial Universidad del Rosario, 2014, pp. 93-95. Textos de ciencias humanas collection. ISBN: 978-958-738-543-4.

https://doi.org/10.7476/9789587385434.0023.

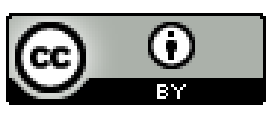

All the contents of this work, except where otherwise noted, is licensed under a Creative Commons Attribution 4.0 International license.

Todo o conteúdo deste trabalho, exceto quando houver ressalva, é publicado sob a licença Creative Commons Atribição $\underline{4.0}$.

Todo el contenido de esta obra, excepto donde se indique lo contrario, está bajo licencia de la licencia $\underline{\text { Creative }}$ Commons Reconocimento 4.0 . 


\title{
22. De recuerdos, memorias y nostalgias
}

\author{
Cuando se acerca el mediodia, las sombras son todavia bordes \\ negros, marcados, en el flujo de las cosas, y están dispuestas a \\ retirarse quedas, de improviso, a su armazón, a su misterio. \\ Walter Benjamin, Discursos interrumpidos I
}

- ¿A qué huele?

- iComo a algo dulce!

Sí, un recuerdo dulce retorna a mí, vistiendo la camisa azul marino que me mandaron los primos de Estados Unidos. De ellos tengo un recuerdo muy vago de hace muchos años que vieron junto con la tía Oliva y su esposo Ovidio. Su equipaje y su ropa, todo olía dulce, dulce.

Recuerdo también una buseta roja de transportes Castilla — que el tío Jaime había conseguido - en la que fuimos a recogerlos al aeropuerto. Tal vez haya sido para el entierro la abuela Laura. Les llevamos flores. Tendría yo acaso unos nueve o diez años. Por aquellos días también soñaba con ir a Nueva York, como muchos en la familia... pero yo lo pensaba porque creía que todo allí sería dulce: los dólares, los carros, Mickey Mouse, la estatua de la Libertad... Aquella vez, la tía Oliva solo vestía de negro. Sí, había muerto alguien. Ya lo recuerdo...

Pero después volvió en varias ocasiones. Vino a saludar, a celebrar... y vestía de colores. En algunas otras ocasiones su esposo Ovidio vino solo. Siempre nos saludaba. La tía Oliva, físicamente, se parece mucho a mi mamá. Y de sus hijos siempre he tenido la misma imagen. Un par de chicos blancos en un cuadro colgado en casa de la tía Irene. Willi es el menor. Me parece una versión masculina de mi prima Omaira. Ricky era el más grande, y no solo por su tamaño... Me parecía un típico gringo de las películas. Los imagino en primavera o en otoño, siempre 
entre flores. Quizá sea por las flores que esos recuerdos son dulces... Las flores son dulces y evocan sensaciones.

Estoy evocando recuerdos de mis primos y añorando volver a ver a la tía, que con los años le tiene más miedo a montar en avión. No sé si mis ancestros tuvieron tanta conciencia de dónde estaban y adónde iban. No sé cómo se sintió el abuelo en Nueva York. No alcanzo a imaginarlo por el barrio latino... Yo tampoco me veo paseando por Atlantic City. Pero imaginando nuestro transcurrir por los años entre pueblos y grandes ciudades de esperanzas y añoranzas de una vida mejor... escucho a mamá decir que la tía Oliva fue a buscar un lugar mejor... Mamá siempre ha querido ir a visitarla... Espero que así sea. Entonces me dirá cómo es el olor de Nueva York.

$\infty \infty \infty$

Este texto nos está dejando ver a la organización familiar en pleno proceso de construcción, deconstrucción y reconstrucción en medio de inevitables tensiones, conflictos, redefiniciones y otras ambigüedades que nos llevarán a transformaciones radicales generadoras de varias crisis, por cuenta de factores como los que se destacan a continuación:

- La democratización en las relaciones familiares, que debilita la supremacía de la autoridad paterna y fortalece la participación y autonomía de los otros miembros.

- Una diversificación en las formas de unión y las modalidades de convivencia, en especial el aumento de la unión libre con o sin residencia compartida, la separación y el madresolterismo.

- Un descenso en las mujeres separadas, como resultado de nuevas uniones.

- Un aumento en la viudez femenina, asociada con el notorio incremento de muertes masculinas por causas violentas, en especial en los varones entre 20 y 44 años.

- Fracturas irreversibles en la división sexual tradicional: el esposo-padre ya no se percibe como único proveedor económico de la familia, y el único representante legal y guardián de sus hijos, a la vez que la esposa-madre deja de ser vista como una exclusiva responsable de proveer cuidados y servicios domésticos.

- La disminución de la fecundidad, reducida en más de la mitad del número medio de hijos por mujer: de 7,4 en 1964 a 3,05 en 1993, 1,9 en 2012, lo que a su vez disminuye el tamaño medio de la familia. 
- Hay un número creciente de parejas que nunca tienen hijos.

- Mayor crecimiento de la participación femenina: incrementada de $36,84 \%$ a 49,07\% entre 1982 y 1995.

Estas transformaciones radicales las ha estado experimentando nuestra sociedad en el seno de las funciones tradicionales de la familia. Por ejemplo, la conyugalidad, entendida como convivencia vitalicia para organizar la sexualidad y garantizar societal y familiarmente la legitimidad, cambia en la medida en que la gratificación sexual no requiere ni la convivencia ni la legalidad de la unión. Surgen así, o se fortalecen, diversas formas de unión y de reproducción de la prole, como lo había planteado Engels (1884), en Elorigen de la familia, la propiedad privaday el Estado. Etiológicamente, familia viene del latín famulus, que quiere decir esclavo doméstico, donde la familia es el conjunto de los esclavos pertenecientes a un mismo hombre (Engels, 1884). Por tradición cultural, o por determinismo histórico, estos esclavos se liberan o se condenan aún más, como las madres, quienes están llamadas a asumir la carga filial en las crisis de los famulus. Así lo demuestra la creciente jefatura económica de la mujer urbana, heroína separada o madre soltera de la que esta etnografía nos deja ver algunos episodios. 